\title{
Search and Seizure: A No-Man's Land in the Criminal Law
}

\author{
John Kaplan*
}

"T HE VERY strength of our common law," Benjamin Cardozo has written, "its cautious advance and retreat a few steps at a time is turned into a weakness unless bearings are taken at frequent intervals so that we may know the relation of the step to the movement as a whole." As the past few volumes of the United States Reports indicate, the Supreme Court has, after some ten years of relative inattention, once again directed its concern to the problems of search and seizure. ${ }^{2}$

Although these problems are among the most frequently litigated in the criminal law, their scope and impact are not fully revealed in the reported opimons. Where an accused is apprehended in possession of contraband such as narcotics or bootleg liquor, his sole defense will usually turn on the legality of the search and seizure. If the district judge determines that they were proper, the accused will often plead guilty, ${ }^{3}$ hoping for a lighter sentence, rather than gamble on the chance that the district judge might be reversed. ${ }^{4}$ Similarly, where the search and seizure are held illegal, the Government, having no right of appeal, ${ }^{5}$ will often be obliged to dismiss the prosecution.

The basic right asserted in most cases involving search and seizure is, of course, protected by the fourth amendment, which provides that:

The right of the people to be secure in their persons, houses, papers, and effects, against unreasonable searches and seizures, shall not be violated, and no Warrants shall issue, but upon probable cause, supported by Oath or affirmation, and particularly describing the place to be searched, and the persons or things to be seized.

* Member, California, New York, and District of Columbia Bars.

1 Cardozo, The Growth of THE LAW 5-6 (1924).

2 During the past four terms, the Court has handed down eleven cases involving federal search and seizure, whereas in the seven terms before that, the Court considered only five.

3 This fact explains in part why so many cases are terminated without trial by pleas of guilty. See Wood, Informal Relations in the Practice of Criminal Law, 62 AM. J. Socrolocy 48 (1956).

4 Where facts are found on the basis of conflicting testimony, reversal is especially rare. See Nichols v. United States, 176 F.2d 431 (8th Cir. 1949).

5 United States v. Mattingly, 285 Fed. 922 (D.C. Cir. 1922). A right of appeal, however, is granted the government in narcotics cases. See 18 U.S.C. $\$ 1404$ (1958). In United States v. Bush, 283 F.2d 51 (6th Cir. 1960), the court considered a government appeal in a bootlegging case. There, however, no one appears to have noticed the jurisdictional defect. 
Although the amendment encompasses arrest as well as search, its history shows that the founders of the Republic were much more concerned with freedom from arbitrary search than from arrest. ${ }^{6}$

In this day there is little to choose between the indignity of returning home to find police officers ransacking one's belongings and papers, and that of being arrested, possibly in late afternoon, and required to spend a night in jail before bail can be taken and an arraignment hearing held. Nonetheless, the events of the mid-18th century had focused the attention of the Framers primarily on the search for and seizure of evidence.

At early common law the search warrant was unknown and any unconsented entry onto the land of another was a trespass. The first use of the search warrant was confined to cases where the owner of chattels was willing to swear-with a suit for trespass certain to follow were he mistakenthat property stolen from him was lodged on the land of another. As Lord Camden stated,

The owner must swear that the goods are lodged in such a place.- $\mathrm{He}$ must attend the execution of the warrant to shew them to the officer, who must see that they answer the description.-And, lastly, the owner must abide the event at his peril: for if the goods are not found, he is a trespasser; and the officer being an innocent person, will be always a ready and convenient witness against him. ${ }^{7}$

From these beginnings the use of the search warrant gradually developed to allow search, not only for stolen property, but for any property which the private citizen was not permitted to possess. This included two main types of contraband which were subject to forfeiture to the Crowngoods upon which the proper tax had not been paid, and the means or instrumentalities of a crime. ${ }^{8}$ In each of these cases the property seized might also be used as evidence, but a necessary condition of the seizure was the fact that the citizen was for some reason not entitled to possess the property.

The attempt of Lord Hamilton, the Secretary of State, to broaden this right of search led to the landmark case of Entick v. Carrington. ${ }^{9}$ There the Secretary had issued administrative search warrants presuming to authorize search of private homes and papers for defamatory material usable as evidence to convict for criminal and seditious libel. Armed with these, officers

6 The fourth amendment has also been applied to allow quashing of government subpoenas which are unreasonably broad in scope. See Boyd v. United States, 116 U.S. 616 (1886). This use of the fourth amendment occurs very rarely, however. See Petition of Borden Co., 75 F. Supp. 857 (N.D. Ill. 1948).

7 Entick v. Carrington, 19 Howell's State Trials 1029, 1067 (1765).

8 A modern outgrowth of this principle can be found in INT. REv. CoDE of 1954, § 7302.

819 Howell's State Trials 1029 (1765). See also Money v. Leach, 3 Burr. 1742 (1765); Huckle v. Money, 2 Wilson 205 (1763). 
searched the home of one of the Secretary's political enemies. ${ }^{10}$ In the subsequent suit for trespass the court held the administrative warrants to be illegal and affirmed the award of substantial damages stating,

Lastly, it is urged as an argument of utility, that such a search is a means of detecting offenders by discovering evidence. I wish some cases had been shewn, where the law forceth evidence out of the owner's custody by process....

In the criminal law such a proceeding was never heard of; and yet there are some crimes, such as for instance murder, rape, robbery and housebreaking, to say nothing of forgery and perjury, that are more atrocious than libelling. But our law has provided no paper-search in these cases to lielp forward the conviction. ${ }^{11}$

In the Colonies, however, judicial intervention against such general searches was unavailable. During the French and Indian War, the British, to suppress smugghing, to secure revenue for the conduct of the war, and to prevent trade with the French West Indies, had issued writs of assistance in the nature of general search warrants permitting officers to search where they pleased for smuggled goods. James Otis resigned his post as attorney general of Massachusetts to carry on a legal battle against the offensive searches, but despite his efforts the courts sustained their power to issue the writs. ${ }^{12}$

That these searches and Otis's legal struggle against them had a significant impact on colonial thinking was emphasized by John Adams long after the Revolution: "Then and there was the first scene of the first act of opposition to the arbitrary claims of Great Britain. Then and there the Child Independence was born." 13

The behavior of the colonial legislatures provides other proof of just how galling the general warrants were to the framers of the Constitution. In 1776 no less than four of the Colonies enacted declarations of rights specifically providing agamst general search warrants. ${ }^{14}$ These provisions provided the basis of the fourth amendment.

The preoccupation of the founders with search by government officials as distinguished from arrest is also shown by the behavior of the early Congresses. Although no provision was made for any federal law of arrest, ${ }^{16}$ the first volume of Statutes at Large contains four acts ${ }^{16}$ authorizing search

10 See 3 Churchind, A History of the Engrisin Speaking Peoples 164-69 (1957).

11 Entick v. Carrington, 19 Howell's State Trials 1029, 1073 (1765).

12 See Fraenkel, Concerning Searches and Seizures, 34 HARv. L. REv. 361, 364 (1921).

13 Quoted in Fraenkel, id. at 365.

14 See Henry v. United States, 361 U.S. 98, 100-01 (1959).

15 See Orfield, Warrant of Arrest and Summons Upon Complaint in Federal Criminal Procedure, 27 U. Cnvc. L. Rev. 1, 20 (1958).

${ }^{16}$ Act of July 31, 1789, ch. 5, § 24, 1 Stat. 43; Act of August 4, 1790, ch. 35, § 48, 1 Stat. 170; Act of March 3, 1791, ch. 15, § 32, 1 Stat. 207; Act of March 2, 1799, ch. 22, \$ 68, 1 Stat. 677. 
warrants on oath before justices of the peace for daytime searches for various types of contraband, such as tax-unpaid liquors. Subsequent statutes permitted search warrants for books and papers relating to customs fraud, ${ }^{17}$ counterfeit money, ${ }^{18}$ and obscene literature. ${ }^{10}$ It was not until 1917 that a general search warrant provision was enacted allowing search for stolen goods or property used in the commission of any felony..$^{20}$

The present grounds for issuance of a search warrant, with certain exceptions scattered through the statutes, ${ }^{21}$ are stated in rule 41 of the Federal Rules of Criminal Procedure. ${ }^{22}$ These rules, reflecting the common law development of the search warrant, provide that warrants may be issued to authorize search (1) for stolen or embezzled property, and property intended for use or which has been used as the means or instrumentality of committing a crime (2) where probable cause appears (3) from an affidavit made before a magistrate or United States Commissioner to believe that (4) at described premises (5) the specifically identified property can be found.

Of these five restrictions it would appear that only the first cannot be justified by any desire to protect the privacy of the citizen. In effect, this requirement provides that no search warrant may be secured to discover evidence of a crime unless the evidence happens to fall into certain restricted categories, by far the most common of which is the instrumentality of the crime. For instance, a knife used in a stabbing is a legitimate object of search, since it is an instrumentality of a crime. ${ }^{23}$ A blood-spattered garment, however, would in all probability not be a proper subject of search,

17 Act of March 3, 1863, ch. 76, § 7, 12 Stat. 740.

18 Act of March 3, 1901, ch. 854, § 911, 31 Stat. 1337.

19 Act of August 27, 1894, ch. 349, § 12, 28 Stat. 549.

20 Act of June 15, 1917, ch. 30, tit. XI, 40 Stat. 228.

2146 Stat. 752 (1930), 19 U.S.C. § 1595 (1958) (smuggled goods); 18 U.S.C. § 1405 (1958) (narcotics).

22 "Rule 41. SEARCH AND SEIZURE

(a) Authority to Issue Warrant. A search warrant authorized by this rule may be issued by a judge of the United States or of a state, commonwealth or territorial court of record or by a United States Commissioner within the district where the property sought is located.

(b) Grounds for Issuance. A warrant may be issued under this rule to search for and seize any property.

(1) Stolen or embezzled in violation of the laws of the United States; or

(2) Designed or intended for use or which is or has been used as the nueans of committing a criminal offense; or

(3) Possessed, controlled, or designed or intended for use or which is or has been used in violation of Title 18, U.S.C., Sec. 957.

(c) Issuance and Contents. A warrant shall issue only on affidavit sworn to before the judge or commissioner and establishing the grounds for issuing the warrant. If the judge or commissioner is satisfied that grounds for the application exist or that there is probable cause to believe that they exist, he shall issue a warrant identifying the property and naming or describing the person or place to be searched."

23 See Gouled v. United States, 255 U.S. 298, 308 (1921). 
although it might be equally persuasive of guilt. ${ }^{24} \mathrm{~A}$ letter containing admissions of guilt would not be a proper object of search ${ }^{25}$ unless it also conveyed information necessary or useful in the commission of the offense. ${ }^{20}$

A recent case provides an example of the application of the means and instrumentalities rule at its worst. ${ }^{27}$ Petitioner, apparently a wholesale interstate dealer in obscene materials, moved to suppress certain obscene materials. The materials had been seized pursuant to a searcli warrant which alleged that they were intended for use in a conspiracy to transport obscene materials by common carrier in interstate commerce. ${ }^{28}$ The court, however, drew a distinction between materials being used as a means of committing the conspiracy and being used in the conspiracy. "The difference," the court stated, "changes the character of the property for which the warrant is sought from that properly the subject of a warrant to merely evidentiary material." The court went on to hold-as is technically correct-that "the obscene materials cannot be said to be the means or instrumentality of depositing itself for an interstate shipment with any carrier."20 Therefore, the evidence was ordered suppressed.

The requirement that the object seized be an instrumentality of crime owes its existence to the principle that such articles are forfeit to the government which in turn seems to be derived from the deodand of the early common law. ${ }^{30}$ In the 13 th century a metaphysical fault was imputed to an inanimate object such as a wagon or sword which had caused an injury. This fault made the object a deodand which could be seized, condemned, and after purification sold by the Crown. It is difficult to believe, as has been suggested, ${ }^{31}$ that this metaphysical principle has been frozen into our Constitution. Rather it would seem that such a restriction on search, completely unrelated to protecting any legitimate interest in the privacy of the individual, would have been jettisoned years ago. Judge Learned Hand acknowledged this anomaly, but considered that the rule had value despite its irrationality, since any restriction on the right of search by government officials protected pro tanto the privacy of the individual. ${ }^{32}$ The privacy of

24 Morrison v. United States, 262 F.2d 449 (D.C.Cir. 1958) ; but see Morton v. United States, 147 F.2d 28 (D.C. Cir. 1945).

25 Woo Lai Chun v. United States, 274 F.2d 708 (9th Cir. 1960).

${ }^{26}$ Cf. United States v. Clancy, 276 F.2d 617 (7th Cir. 1960), rev'd on other grounds, 365 U.S. 312 (1961).

27 United States v. Loft on 6th Floor of Bldg., 182 F. Supp. 322 (S.D.N.Y.1960).

2818 U.S.C. \& 1462 (1958).

29 United States v. Loft on 6th Floor of Bldg., 182 F. Supp. 322, 324-25 (S.D.N.Y. 1960).

30 See 2 Poliock \& Maitiand, The History of English Law 473 (2d ed. 1898).

31 Schwartz, On Current Proposals to Legalize Wiretapping, 103 U. PA. L. REv. 157, 163 (1954).

32 United States v. Poller, 43 F.2d 911, 914 (2d Cir. 1930) ("Limitations on the fruit to be gathered tend to limit the quest itself"). 
the individual, however, would be just as well served by a restriction on search to the even-numbered days of the month. Presumably this would have an equal restrictive effect. And it would have the extra advantage of avoiding hair-splitting questions such as whether a passbook indicating the deposit of bank robbery loot was a fruit or instrumentality of the crime or merely evidence thereof. ${ }^{33}$

The four other requirements for a search warrant are more directly related to the purposes of the fourth amendment. The requirement that before the citizen's privacy can be invaded there inust be sufficient reason or probable cause to believe that the search will be fruitful is, of course, an outgrowth of the principle that the rights of society to secure evidence against lawbreakers must be balanced against the right of the private citizen to be let alone. At least the right of search should be confined to situations where there is some objective reason to beheve that the benefit to society will outweigh the invasion of the citizen's privacy. ${ }^{34}$

The third requirement - that the probable cause must be determined by a magistrate or a United States Commissioner before the search is undertaken-is basic to the entire concept of the search warrant. The policy determination made in the fourth amendment demands that, except in certain very restricted circumstances, the police officers engaged in the "relatively competitive enterprise of ferreting out crimes"35 cannot themselves be the judge of when there exists probable cause to believe that a legitimate object of a search may be found. No matter how obviously a search may be in order, they must, in general, ${ }^{36}$ present their evidence of probable cause to a dispassionate magistrate who himself must then make that determination, and specify the area and objects of the search. ${ }^{37}$ A necessary corollary of this rule is that the doctrine of harmless error cannot apply. The entire purpose of the fourth amendment would be frustrated if officers could defend a search without warrant on the ground that since a search warrant

33 United States v. Howard, 138 F. Supp. 376, 381 (D.C. Md. 1956).

Despite the large number of cases treating seizure of betting slips and other gambling paraphernalia no reported case has considered the question of what are the instrumentalities of evasion of the tax on wagers. See INT. REv. CODE of 1954, § 7201.

34 See Brinegar v. United States, 338 U.S. 160, 183 (1949) (dissenting opinion) wherein Justice Jackson suggests that a lesser degree of probable cause sliould be necessary in searches involving more serious crimes. This suggestion has not been followed overtly in any reported federal case.

35 Johnson v. United States, 333 U.S. 10, 14 (1948).

36 The rule is usually stated to have an exception where circumstances such as the inminent destruction of evidence make resort to a magistrate impracticable. See Jolinson v. United States, supra note 35 , at 14 . No case, however, has allowed the search of a dwelling on this ground. See Eng Fung Jem v. United States, 281 F.2d 803 (9th Cir. 1960).

37 Marron v. United States, 275 U.S. 192 (1927); Woo Lai Chun v. United States, 274 F.2d 708 (9th Cir. 1960). 
clearly could have been procured the defendant had not been prejudiced by the failure to present evidence to the magistrate.

On the other hand, it should be realized that this requirement of resort to a warrant in cases where no magistrate would conceivably deny one can lead to difficult law enforcement problems. For example, let us say that an officer selling tickets to the policemen's ball glances through a window and observes a large pile of white powder, together with the typical paraphernalia of the narcotics peddler-hypodermic syringes, balances, and bindle paper. He is then in a most unenviable position. If he leaves to procure a search warrant, the narcotics may not be there when he returns. If he shouts to bystanders to fetch help he may alert an occupant of the house who could dispose of the narcotics down the toilet without a trace before the officer could enter the house. Lastly, if he enters the house without a warrant to seize the narcotics le will violate the fourth amendment. It is perhaps expecting too much of hin to ask that lie merely shrug his shoulders and philosophically conclude that his Hobson's choice is the price we must pay for the great guarantees of the fourth amendment.

The next requirement-that the warrant describe the premises to be searched-forces the police officers to do more than merely connect the objects of search with a prospective defendant. They must, in the usual case, produce before the magistrate probable cause to believe that the property subject to search and seizure is being kept at the specific place mentioned in the warrant. In the commission of certain offenses, such as the operation of stills, distinctive odors emanate, relatively bulky products are produced, and large amounts of raw material are required. Therefore, the problein of locating the offending property is usually no more difficult than the problem of identifying and locating the offenders. However, the instrumentalities of other crimes such as narcotics and wagering tax violations are relatively small and easy to conceal. Should the "pusher" or "runner" operate out of his home and one or more places of business it may be inpossible for the police officers to produce probable cause, regardless of their suspicions, that the offending property is at any given place. In such a case no search warrant will be procurable, despite the evidence connecting the individual with the crime.

A recent case out of the Court of Appeals for the District of Columbia provides an unusual example of the problems caused by this requirement. ${ }^{38}$ Police officers had for some time kept one of a row of houses, 1106 18th Street NE., under surveillance. From the movements of well-known gamblers in and out of the house, together with deliveries being made to the house, they had ample probable cause to believe that 1106 18th Street NE.

38 Keiningham v. United States, 287 F.2d 126 (D.C. Cir. 1960). 
was being used as the center of a large illegal gambling operation. The officers procured a search warrant for 1106 18th Street NE. from the United States Commissioner, but upon executing the warrant they were surprised to find neither gambling paraphernalia nor gamblers in the house. This was especially baffling because the police had seen two known gamblers carrying large brown envelopes enter 1106 and from their surveillance of all the exits they knew that no one had left. The mystery was unravelled when on an upper floor of 1106 the police discovered that the wall between 1106 and 1108, the next house in the row, had been cut through. It was 1108 rather than 1106 that was the nerve center of the gambling operation and the members of the conspiracy had merely entered and left 1106 as a ruse to mislead the police. The ruse was successful; the search warrant for 1106 was lield not to cover any entry into 1108. The evidence found on 1108 was therefore ordered suppressed.

The last requirement- that the warrant particularly describe the goods to be seized-serves to allow the magistrate control over the seizure as well as the search. In practical effect it is most often invoked to prevent the seizure of unlisted and usually unexpected items which are found in an otherwise legitimate search pursuant to warrant. ${ }^{39}$ Here again the application of the harmless error concept to the seized evidence would defeat the application of the rule. Police officers, having legitimately discovered these extra objects could always place them under guard and then procure a search warrant for their seizure. On the other hand, simce the primary evil aimed at by the fourth amendment is the invasion of privacy by means of the search as distinguislred from the seizure, the courts liave been reluctant to require the police to take this purely formal step. The lower federal courts, despite the flat statement to the contrary from the Supreme Court, ${ }^{40}$ have evolved a rule that officers acting under a valid warrant may seize unspecified property reasonably related to the purpose of the search. ${ }^{41}$

Although the origins of the search warrant are deeply rooted in the common-law concepts of ownership and trespass, the scope of the fourth amendment has in the main been tailored to protect privacy, the primary concern of its Framers. The reference in the amendment to louses, papers, and effects makes it clear that not every intrusion upon private property ${ }^{42}$ without a search warrant is prohibited even thougl at common law the simple entry onto the open field of another required a warrant..3 Government officers today may be guilty of a technical trespass if they enter upon the

\footnotetext{
38 See United States v. Lester, 21 F.R.D. 376, 382 (W.D.Pa. 1957).

40 See Marron v. United States, 275 U.S. 192, 196 (1927).

41 United States v. Joseph, 174 F. Supp. 539, 545 (E.D.Pa. 1959) and cases cited therein.

42 Hester v. United States, 265 U.S. 57, 59 (1924).

43 See Walker v. United States, 225 F.2d 447 (5th Cir. 1955).
} 
open land of another, but none of the sanctions enforcing the fourth amendmend will be invoked. It is not clear whether land within the curtilage, or fence surrounding the hoine, ${ }^{44}$ is within the purview of the fourth ainendment, and although the problem has been vigorously debated, ${ }^{45}$ cases presenting the question have occurred only rarely. The most common rule extends the protection of the fourth amendment to all structures used in relation to a hoine or business, ${ }^{46}$ whether or not within the curtilage, ${ }^{47}$ and whether owned, leased, or merely occupied. ${ }^{48}$

Indeed, the fourth amendment has in some cases extended protection to the right of privacy in areas entirely unprotected by the common law. For example, even though mail may be in the custody and possession of the government, a search warrant is necessary before government officials may open any sealed first-class letter. ${ }^{49}$ Automobiles, too, are protected from unreasonable search, although in view of their great mobility the concept of reasonability is somewhat extended. Search without a warrant is allowed when police officers have probable cause to believe that objects subject to search will be found and no time is available to procure a search warrant..$^{50}$

In one major area, however, the common-law concepts of trespass have been vigorously applied with little consideration for the privacy of the individual. Eavesdropping and "bugging" by electronic detecting and amplifying devices would seem to represent the ultinate invasion of privacy. These practices intrude on conversations so private they would never be reduced to writing. And since the victim is generally unaware of their occurrence, he cannot protest against them. ${ }^{51}$ Because of these factors the courts, realizing the basic purposes of the fourth amendment, have had no trouble holding that in certain circumstances eavesdropping can amount to a search and seizure. ${ }^{52}$ They have, however, inported the technical concepts of trespass into this field and have held that only where a physical invasion of the citizen's dwelling or office has occurred will any conversations overheard

44 In Polk v. United States, No. 17,017, 9th Cir., May 23, 1961, the 9th Circuit remanded a case for further evidence on the "degree of privacy" the defendant enjoyed in his back yard.

45 Janney v. United States, 206 F.2d 601, 603 (4th Cir. 1953).

46 Martin v. United States, 155 F.2d 503, 505 (5th Cir. 1946).

47 United States v. Jeffers, 342 U.S. 48 (1951).

48 Oliver v. United States, 239 F.2d 818 (8th Cir. 1957). See Annot., 61 A.L.R.2d 1282 (1958).

49 See Carroll v. United States, 267 U.S. 132, 156 (1925).

50 Brinegar v. United States, 338 U.S. 160 (1949); United States v. Roberts, 90 F. Supp. 718 (E.D. Tenn. 1950).

51 Wiretapping, which might logically be included here, has been held not covered by the protection of the fourth amendment. The citizen, however, is given even greater protections against this intrusion. See Kamisar, The Wiretapping-Eavesdropping Problem: A Professor's View, 44 Minn. L. REv. 891 (1960).

52 Compare Goldman v. United States, 316 U.S. 129, 134-35 (1942), with Irvine v. California, 347 U.S. 128, 132 (1954). 
be treated as illegally obtained. ${ }^{53}$ Thus, the police seem to be free to eavesdrop and "bug" at will, provided that they neither set foot on nor allow any physical part of their apparatus to project into the area protected by the fourth amendment.

It can be argued that hidden microphones or electromic devices are an essential tool of legitimate police investigation ${ }^{54}$ and, contrariwise, that these modern devices provide the most realizable present threat of a 1984 model police state..$^{55}$ In neither of these cases are the technical requirements of trespass relevant. Although we must make some adjustment between the rights of society to apprehend lawbreakers and the rights of the individual to privacy, the rules of trespass do not provide any meaningful guides. Furthermore, in view of the rapidity of development in techniques of electronic detection and amplification of sound, it would seem that before very long almost every siguificant invasion of privacy in this area may be just as effectively made without a trespass as with. ${ }^{56}$

Since the Supreme Court has in more than one case attempted to free the fourth amendment from the shackles of the common law of trespass ${ }^{57}$ it is not too much to hope that when the Court again turns to this problem it will, perhaps through the use of its rule-making power, fashion a more satisfactory rule. In deciding what shape this rule should take we encounter many problems. We must first distinguish conversations listened to with the consent and aid of one of the parties. ${ }^{58}$ In this situation it is difficult to make out any invasion of privacy whether the conversation has taken place at the home of the non-consenting party or over the telephone. All that has happened is that the government has secured a mechanical means of guaranteeing the credibility of its informant who presumably would himself be available to testify as to the conversations.

Where neither of the parties consents, it has been argued that histening with an electronic device is different only in degree from the mininal invasion of privacy that results from carrying on a conversation in a public place or in such loud tones that the passers-by might overhear it. If such

53 United States v. Silverman, 166 F. Supp. 838 (D.D.C. 1958), aff'd, 275 F.2d 173 (D.C. Cir. 1960), rev'd, 365 U.S. 505 (1961).

54 See Silver, The Wiretapping-Eavesdropping Problem: A Prosecutor's View, 44 MnNs. L. REv. 835 (1960) ; Statement of Herbert J. Miller, Jr., Assistant Att'y Gen. in Charge of the Criminal Division, Dep't of Justice, on S. 1086, S. 1221, S. 1495 before the Subcommittee on Constitutional Rights of the Senate Judiciary Committee, May 11, 1961, summarized in N.Y. Times, May 12, 1961, p. 16, col.3.

65 See Paulsen, Safeguards in the Law of Search and Seizure, 52 Nw. U. L. Rev. 65 (1957).

50 See Dase, Schwartz \& KNowiton, THE EaveSdroppers 350 (1959).

57 On Lee v. United States, 343 U.S. 747 (1952); McGuire v. United States, 273 U.S. 95 (1927).

68 See Rathbun v. United States, 355 U.S. 107 (1957). See also On Lee v. United States, 343 U.S. 747 (1952). 
an analogy is valid it merely illuminates one more instance where a difference in degree sufficiently great becomes a difference in kind.

It is possible that a workable solution can be developed whereby a warrant showing probable cause would be required before any mechanical device-with or without a trespass-could be used to eavesdrop on a private conversation. ${ }^{59}$ However, since the rapid advance in our technology has prevented satisfactory guides from being evolved over the years, any specific balancing would have to be based in great part upon a visceral reaction to eavesdropping. ${ }^{60}$ It might well be decided, as a result of this balancing, that the physical invasion of a private home for the purpose of eavesdropping should not be countenanced no matter how strong the showing of probable cause. On the other hand, it might be that certain crimes, such as kidnaping, require such immediate and decisive police action that they should be treated differently from the usual narcotics, bookmaking, and bootlegging offenses, and that in such cases a warrant should be permitted.

As if the practical problems involved were not enough, various writers have raised a conceptual one-that a conversation is mere evidence as distinguished from the instrumentality of a crime, and hence no warrant can constitutionally be issued directing its seizure "by eavesdropping." Even if the means and instrumentalities test were of constitutional dimension there is no sensible reason to apply it to other than tangible evidence. To restrict government action unduly in the name of metaphysics is no better than to sacrifice the privacy of the individual to the common-law technicalities of tort law.

The Supreme Court this term considered a case presenting an admirable opportunity to shed some light on the problems of eavesdropping. In Silverman v. United States, ${ }^{62}$ District of Columbia police had driven a spike approximately halfway through a party wall and using this as a pickup for their microphone were able to listen to conversations in the defendant's louse. The District Court, possibly finding that the spike had not gone halfway through the wall and therefore had not trespassed on the defendant's property, held that there was no illegality in the eavesdropping. The Court of Appeals affirmed and the Supreme Court on certiorari reversed. In the short majority opinion by Justice Stewart the Court made it clear that the

${ }^{59}$ Cf. Goldman v. United States, 316 U.S. 129, 140 n.6 (1942) (dissenting opinion).

${ }^{60}$ See Kamisar, The Wiretapping-Eavesdropping Problem: A Professor's View, 44 MinN. L. Rev. 891, $928 \mathrm{n} .197$ (1960). The professor suggests that this be done on a case-by-case basis without reference to the fourth amendment by nieans of the "supervisory power" of the Suprenie Court.

61 See Williams, The Wiretapping-Eavesdropping Problent: A Defense Counsel's View, 44 Minv. L. Rev. 855, 86 (1960).

02365 U.S. 505 (1961). 
essential values mvolved are the rights of privacy under the fourth amendment, not the technicalities of property law. Nonetheless, the opinion distinguished previous cases permitting eavesdropping, stating that here there had been an "unauthorized encroachment," "physical invasion," and "actual intrusion," since once the spike microphone had touched the heating duct of the defendant's house it "became in effect a giant microphone running through the entire house." ${ }^{\prime 3}$ The Court refused to reexamine Goldman v. United States, ${ }^{64}$ where police had been permitted to eavesdrop, using a detectaphone attached to the wall of the office adjoining that of the defendant. As a inatter of either logic or physics it is very difficult to see how the heating duct in Silverman "became in effect" any more a microphone than the walls in Goldman. Justice Douglas, in his concurrence, took the view that "the privacy of the home was invaded" and "no search warrant was obtained as required by ... Rule 41 of the Federal Rules of Criminal Procedure." ${ }^{65}$ This view, however, is less than candid since at least under the present wording of rule 41 the means and instrumentalities test would bar any warrant for eavesdropping. In other words, it is safe to say that the problems of eavesdropping after the Silverman case are even more confused than before.

Although the fourth amendment was aimed primarily at protecting the citizen against the invasion of his privacy by police searching for evidence, its guarantees are somewhat broader. The fourth amendment applies to seizure as well as search and though the validity of a seizure will usually stand or fall with that of the search which preceded it, this is not always so. The most obvious example where a legal search may lead to an illegal seizure occurs when police, executing a search warrant, seize evidence not related to items described in the search warrant or not falling within the categories set out in rule $41 .^{66}$ Moreover, in one case where government agents rightfully searched a cabin, their seizure of all its contents and subsequent transportation of them some two hundred miles was held to be so unreasonable as to render all the contents-not merely the excess over a reasonable amount-illegally seized. ${ }^{67} \mathrm{On}$ its facts this decision is subject to much criticisin, since the government agents had good reason to believe that there might be extremely small and well-concealed instruments of espionage in the cabin. ${ }^{68}$ The general principle enunciated, however, remains valid; the reasonability of the seizure will be somewhat more nar-

$63 I d$. at 509.

64316 U.S. 129 (1942).

65 Silverman v. United States, 365 U.S. 505, 513 (1961).

$B 6$ United States v. Lester, 21 F.R.D. 376 (W.D. Pa. 1957).

67 Kremen v. United States, 353 U.S. 346 (1957).

${ }^{88}$ See Abel v. United States, 362 U.S. 217 (1960). 
rowly limited than that of a search. Thus, where officers having legitimate business in a home or office see contraband in plain view, they cannot seize it without a warrant, but must guard it until a warrant can be procured.0.$^{00}$

A questionable application of the distinction between search and seizure appears in one recent case ${ }^{70}$ where an automobile was rightfully taken into custody by governinent officials. It was necessary to search the automobile so that its contents could be inventoried for eventual return to the defendant. Narcotics were found during the search. Despite the fact that these narcotics had rightfully come into possession of the government, the court held that the evidence was inadmissible. Apparently the only proper way that the agents could have proceeded was to secure a search warrant directed to the rightful custodian of all property checked with the police. ${ }^{\mathbf{1 1}}$ Only after the police had made this transfer from one department to another could the evidence have properly been introduced. It is difficult to see what legitimate interest of the defendant is protected by this procedure.

The remedies of the citizen against officials transcending the limits of the fourth amendment are three-fold. First, he can attempt to have criminal prosecution instituted against the offending officers under a federal statute providing criminal penalties for a wilfully illegal search by government officials. $^{72}$ The ineffectiveness of this means of redress is demonstrated by the fact that the annotations to this statute reveal no case where a prosecution for this crime has ever been instituted. A second and more likely remedy is by way of civil suit for trespass either under state law ${ }^{73}$ or possibly under a right implied directly from the fourth amendment. ${ }^{74}$ The difficulties inherent in this course have been catalogued elsewhere at length ${ }^{75}$ They include the notorious lack of sympathy on the part of juries toward the most usual victims of illegal search and the inability of many police officers to respond in damages. Furthernore, the broad language in several recent Supreme Court decisions denying recovery even for malicious torts by federal officials acting within the general scope of their authority can easily be interpreted to apply to the area of search and seizure. ${ }^{76}$ At least until the Supreme Court chooses to qualify its recent language it would seem that yet another stumbling block has been placed in the path of the citizen seeking redress for an illegal search.

00 United States v. Scott, 149 F. Supp. 837, 841 (D.D.C. 1957).

70 Rent v. United States, 209 F.2d 893 (5th Cir. 1954).

71 Cf. Travers v. United States, 144 A.2d 889 (D.C. Mun. Ct. App. 1958).

7218 U.S.C. $\$ 2236$ (1958).

73 See Foote, Tort Remedies for Police Violations of Individual Rights, 39 MINN. L. Rev. 493 (1955).

74 See Bell v. Hood, 327 U.S. 678 (1946).

75 See dissenting opinion of Justice Murphy in Wolf v. Colorado, 338 U.S. 25, 41-44 (1949).

76 Barr v. Matteo, 360 U.S. 564 (1959); Howard v. Lyons, 360 U.S. 593 (1959). 
The third and, of course, the most common remedy for an illegal search or seizure is the suppression of any evidence so discovered or obtained. This sanction is at best an indirect one based on the theory that by removing the incentive to lawless criminal law enforcement, the lawlessness will cease $^{77}$ and further, that the most effective punishment for the offending policeman will be the reprimand he receives from his superiors for having provoked the Court into allowing the criminal to escape. ${ }^{78}$

This is a rather drastic sanction to be applied by a society strongly interested in the appreliension of criminals. On the other hand, if the use of such a severe sanction provides the only vindication of what we regard as a fundamental liberty we have no clioice but to protect the liberty. In this decision, however, it is implicit that not every illegality by police officers will call for the suppression sanction. ${ }^{79}$ With but two exceptions, the courts liave insisted that only a constitutional guarantee is important enougl to protect by invoking suppression. ${ }^{80}$ It might be thought, also, that the suppression sanction would be applied only in those areas where it might be thought effective-wilful, or at least negligent, violation by police officers of the fourth amendment. Such is not the case. Even though the requirements of the fourth amendment are sufficiently technical to have baffled many courts, the equivalent of absolute hability has been applied to police officers in these areas. ${ }^{81}$

It is not our purpose here to discuss further the pros and cons of this exclusionary rule. The rule has come under vigorous attack by both courts and commentators and has been vigorously defended as well. ${ }^{82}$ In any event, for the foreseeable future it appears that the rule is firmly ingrained in the federal criminal law.

The exclusionary rule is not only applied to the physical evidence gained by illegal seizure, but also to any testimony by government officials as to facts observed during the course of an illegal search. ${ }^{83}$ Except in one area, the federal courts have almost uniformly applied the primciple that it is necessary to deprive the prosecution of all evidence, testimonial or physical, obtained in violation of the fourth amendment, to prevent the police from gaining any improper advantage. This has even been carried to the extrenie of reversing a conviction because of the admission of fingerprints taken

77 Compare Irvine v. California, 347 U.S. 128 (1954), with Elkins v. United States, 364 U.S. 206 (1960).

78 See Burdeau v. McDowell, 256 U.S. 465 (1921).

79 See Hart v. United States, 130 F.2d 456 (D.C. Cir. 1942).

80 See text following note 171 infra.

81 See Jones v. United States, 357 U.S. 493 (1958).

82 See Waite, The Legal Approach to Crime and Correction, 23 LAw \& ConTEMP. Prob. $594,600-03$ (1958).

83 Williams v. United States, 263 F.2d 487, 489 (D.C. Cir. 1959). 
from the defendant while under illegal arrest, although the prosecution could equally well have used copies of the same prints from the Federal Bureau of Investigation files. ${ }^{84}$ As to statements of the accused, however, the courts have somewhat inconsistently tended to admit in evidence admissions made under illegal arrest or during an illegal search so long as the statements were not coerced and so long as no unreasonable delay occurred between the arrest and arraignment. ${ }^{85}$ The zealous enforcement of the suppression sanction here has had the anomalous result of giving police the impression that the rules governing search and seizure applied only when the material to be seized was intended for use as evidence. Since even illegally siezed contraband is not returnable, officers have often felt free to ignore various legal requirements inerely to get contraband, such as narcotics, out of circulation. Thus, if the defendant is arrested in possession of some narcotics, officers may subsequently search his home for more, realizing, however, that any narcotics discovered may not be used as evidence.

Although any search and seizure of private property without a search warrant is prima facie uulawful, ${ }^{86}$ courts have been somewhat reluctant to apply the relatively severe sanction of letting the known criminal go free. As a result they have established various exceptions to palliate the effect of the suppression rule. Not only do trivial defects in the search warrant ${ }^{87}$ or in the search ${ }^{88}$ not call for the invocation of the suppression sanction, but even where serious violations of the fourth amendment have occurred the defendant inust show his standing to invoke them. ${ }^{80}$ It is true that the ultimate means of discouraging illegal searches would be to render all evidence illegally seized inadmissible in all proceedings. But since the suppression sanction is in great part a vindication of the individual's rights it is reason. able to restrict it to the use of only those individuals whose rights of privacy have been violated, even though others may have a very direct and important interest in showing the illegality of the search and seizure. Accordingly, until very recently the courts have insisted that before a defendant could move to suppress evidence he had to show that the evidence seized belonged to him or was taken from his possession or property. Though on its surface this requirement seems quite reasonable, it placed many defendants in a practical dilemma. To secure standing to ask the court for the suppression of evidence, the defendant would often have to show his possession or ownership of that evidence. Unfortunately for him, if he then failed

84 Bynum v. Umited States, 262 F.2d 465 (D.C. Cir. 1958).

85 Smith v. United States, 254 F.2d 751, 758 (D.C. Cir. 1958).

86 United States v. Roberts, 179 F. Supp. 478 (D.D.C. 1959).

87 See Pera v. United States, 11 F.2d 772 (9th Cir. 1926). But see United States v. Hinton, 219 F.2d 324, 326 (7th Cir. 1955).

88 McGuire v. United States, 273 U.S. 95, 98 (1927).

80 Reisgo v. United States, 285 Fed. 740 (5th Cir. 1923). 
in his suppression motion he would in many common situations have proved the case against himself, since mere possession of contraband such as narcotics or bootlegging equipment is sufficient to constitute a crime. ${ }^{90}$ The Supreme Court last term finally freed the defendant from his quandry by holding that at least in cases where possession itself is the crime charged, the defendant need not prove his possession in order to ask that the evidence be suppressed..$^{91}$ Where possession is not the crime charged, but is merely persuasive evidence of guilt, it is not clear whether the defendant must still prove an important practical element in the prosecution's case before he can invoke his rights under the fourth amendment. ${ }^{92}$ In any event, where evidence is illegally seized from the possession of one not on trial, the rule denying standing to the defendant is still in force.

Another relaxation of the suppression sanction is based on the truism that the citizen cannot complain of any search to which he has consented. Although this principle in the abstract is obvious, it is often very difficult to apply in practice. The average person opeming his door will rarely object when burly police officers appear and ask whether they may search his house. And although it may be argued that these hard-won rights belong only to those who will at least speak up for them, the law does not demand such courage. ${ }^{93}$ On the other hand, there are cases where genuine consent will for some reason be freely and voluntarily given. ${ }^{94}$ The most difficult cases arise where the owner of the premises to be searched is himself under arrest. And it is here that the widest divergence of opinion among various courts appears. In one case a court of appeals held that genuine consent to a search had been given by the defendant who was under arrest, even though the consent had been extracted as a condition of his being allowed to visit his family before arraigument. ${ }^{95}$ Another court of appeals held that even though the defendant had stated, "I have nothing to hide. You can go there and see for yourself," the officers had no right to presume consent since the words might have been, "but the false bravado of the small-time criminal." "96

By far the most important relaxation of the suppression sanction, how-

90 This dilemma has been aptly described by Judge Learned Hand: "Men may wince at admitting that they were the owners of contraband property; may wish at once to secure the remedies of a possessor, and avoid the perils of the part; but equivocation will not serve. If they come as victims, they must take on that role, with enough detail to cast them without question." Connolly v. Medalie, 58 F.2d 629, 630 (2d Cir. 1932).

91 Jones v. United States, 362 U.S. 257 (1960).

$92 I d$. at 265 .

93 See Higgins v. Umited States, 209 F.2d 819 (D.C. Cir. 1954).

94 See United States v. Mitchell, 322 U.S. 65 (1944); United States v. Martin, 176 F. Supp. 262, 268 (S.D.N.X. 1959).

95 United States v. Perez, 242 F.2d 867, 870 (2d Cir. 1957).

96 Judd v. United States, 190 F.2d 649, 651 (D.C. Cir. 1951). 
ever, is the search incident to arrest, a judicially created exception to the requirement of the search warrant. This exception today is so broad that in great part it swallows up the rule and it is safe to say that the number of searches which are upheld under this exception far exceeds the number where a search warrant has been procured.

The present law concerning the search incident to arrest is the product of an unusually tortuous development by the Supreme Court, overlapping, in part, the time during which the Court was formalizing the rigid requirements of the Federal Rules of Criminal Procedure as to the search warrant. At common law police officers might, without a search warrant, lawfully search the person and clothing of someone under lawful arrest. ${ }^{07}$ This right was said to be founded in necessity since a search would have to be made in any event for concealed weapons or other means of making escape. The first mention by the Supreme Court of this narrow exception to the requirement of a search warrant occurred in Weeks $v$. United States, ${ }^{08}$ where the Court stated in a dictum that it was not concerned there with "the right on the part of the Government, always recognized under English and American law, to search the person of the accused when legally arrested." expansion of this doctrine occurred in 1925 when the Court commented that search is allowed of "whatever is found upon [the] ... person or in [the] ... control" of the individual arrested. ${ }^{100}$ The next term, again in dictuin, the Court wrote that the exception covered "the right without a search warrant contemporaneously to search persons lawfully arrested while committing crime and to search the place where the arrest is made ...."101 The gradually expanding dicta of the Supreme Court-from person to control to place of arrest-were first embodied in the holding in Marron v. United States ${ }^{102}$ two years later. There, agents armed with a search warrant to search for and seize liquor arrested the proprietor of a saloon and in making their search came upon certain records of the illegal business. The Court, after holding that the search warrant did not authorize the agents to seize the records, held that the records were nonetheless properly subject to seizure as the instrumentalities of a crime uncovered in the search incident to the arrest of the proprietor.

Two subsequent cases ${ }^{103}$ greatly restricted the Marron case by holding the incident to arrest exception inapplicable in searches not essentially dif-

\footnotetext{
${ }^{07}$ See Dillon v. O’Brien, 16 Cox Cr. Cas. 245 (1887).

08232 U.S. 383 (1914).

90 Id. at 392.

100 Carroll v. United States, 267 U.S. 132, 158 (1925).

101 Agnello v. United States, 269 U.S. 20, 30 (1925).

102275 U.S. 192 (1927).

103 Go-Bart Co. v. United States, 282 U.S. 344 (1931); United States v. Lefkowitz, 285
} U.S. 452 (1932). 
ferent from the search in Marron. One of these cases distinguished Marron on grounds that the evidence seized there was picked up without a search because it was in the plain view of the arresting officials. ${ }^{104}$ Since the record in Marron shows that the evidence was in plain view only because the prohibition agents happened to be looking in a closet, ${ }^{105}$ most courts considered the Marron case as at least partially overruled. ${ }^{106}$ The law remained in this state until Harris v. United States, ${ }^{107}$ where the Court reaffirmed Marron and upheld a search where officers, armed only with a warrant of arrest for a crime involving a forged check, arrested the defendant in his living room and proceeded to search his entire apartment. They found in the bedroom a number of forged selective service registration cards and Harris was successfully prosecuted for the entirely different crime of possession of these cards.

The Harris case did not remain unchallenged for long. Two years later it was emasculated by Trupiano v. United States, ${ }^{108}$ where the Court enunciated the rule that no search could be justified as incident to arrest if it were "practicable" to obtain a search warrant. Acquisition of a search warrant was practicable, the Court stated, where sufficient time existed to obtain one. Were the Trupiano ruling merely a statement that officers must consult a magistrate before searching after an arrest it would have been a time-consuming but not a serious change in the law. However, the swearing out of a search warrant requires some probable cause to believe that the search at a given place will be successful, and the mere fact that the defendant was arrested there is not enough. Thus, since it is more lack of grounds than lack of time which prevents the officers from swearing out a search warrant, the Trupiano ruhing for all practical purposes eliminated the incident to arrest exception. Harris was distinguished on two grounds, neither of which appears to be substantial, the Court stating that "we do not take occasion here to re-examine the situation involved in Harris $v$. United States." 108

Two years later, however, in United States v. Rabinowitz, ${ }^{110}$ the Court was confronted by a situation considerably more favorable to the Government than that in Harris. In Rabinowitz, federal agents armed with an arrest warrant based upon a complaint charging possession of forged stamps had arrested the defendant in his office, and after a search found the very stamps which supported the charge in the arrest warrant. The Second

104 United States v. Lefkowitz, supra note 103, at 465.

105 Marron v. United States, 275 U.S. 192, 199 (1927).

106 See In re Phoenix Cereal Beverage Co., 58 F.2d 953 (2d Cir. 1932).

107331 U.S. 145 (1947).

108334 U.S. 699 (1948).

$108 \mathrm{Id}$. at 708.

110339 U.S. 56 (1950). 
Circuit, however, held the search invalid ${ }^{111}$ on the basis of Trupiano. On appeal, the Supreme Court faced the issue and agreed that Trupiano and Harris could not stand together. It, however, overruled Trupiano, leading Justice Frankfurter to remark bitterly, "especially ought the Court not reinforce needlessly the instability of our day." ${ }^{112}$ The Rabinowitz case has gone unchallenged since, and no Supreme Court case since has struck down a search accompanying a lawful arrest. ${ }^{113}$

Furthermore, although Rabinowitz merely held that the practicability of obtaining a search warrant did not alone vitiate a search incident to arrest, the lower courts have greatly extended this holding. In Rabinowitz the Court relied heavily on certain other factors in support of the search. First, the search was limited in scope to a small room; second, the room was entirely under the control of the defendant; third, it was a business office to which the public was invited; and lastly, the objects of the search were specific articles, the possession of which was a crime. Subsequent lower court cases, however, have expanded the Rabinowitz rule to permit the search of an entire house as incident to a lawful arrest within the home. ${ }^{114}$ In addition, whether or not the possession of the property searched for was a crime has been lield immaterial, providing the property was subject to seizure on some other ground. ${ }^{115}$ Finally, most lower courts have treated the practicability of securing a search warrant as completely irrelevant where the search was made mcident to a lawful arrest. ${ }^{110}$

With the full flowering of the search incident to arrest doctrine the protections set up by the rules concerming search warrants become much less of an impediment to police officers. In many cases an arrest warrant-issued under much more lax conditions-would serve not only as well, but better.

Officers making a search incident to arrest are not required to give an inventory of seized evidence. ${ }^{117}$ Not only will they not be required to state in advance exactly what they intend to seize, but the search incident to arrest, as in Harris, may turn up evidence of crimes entirely different from those specified in the arrest warrant. This is not to suggest that federal officers under the pretext of serving an arrest warrant for one crime can search the home of a defendant to discover evidence of an entirely different crime. ${ }^{113}$ On the other hand, the Supreme Court has recently held that co-

111 Rabinowitz v. United States, 176 F.2d 732 (2d Cir. 1949) (per L. Hand).

112 United States v. Rabinowitz, 339 U.S. 56 (1950).

113 This issue, among others, was presented in Leahy v. United States, cert. granted, 363

U.S. 810 (1960), petition for cert. dismissed on motion of petitioner, 364 U.S. 945 (1961).

114 Williams v. United States, 273 F.2d 781 (9th Cir. 1959).

115 Townsend v. United States, 271 F.2d 445 (4th Cir. 1959) (obscene literature).

110 See Kernick v. United States, 242 F.2d 818 (8th Cir. 1957).

117 Smith v. United States, 254 F.2d 751, 768 (D.C. Cir. 1958).

118 But see Wilson v. State, 161 N.E.2d 484 (Ind. 1959) (arrest for parking violationsearch turned up narcotics). 
operation between investigative branches of government enforcing different statutes does not invalidate an arrest by one branch which turns up evidence useful in a prosecution initiated by the other. ${ }^{119}$ To be sure, the Court stated that no bad faith on the part of the government officials can appear, but it will remain for subsequent decisions to determine just what is meant by bad faith. Where an arrest by one branch of the government is legal and the subsequent search also legal, it seems difficult to hold that the officers' hope of finding proof of other crimes would render a search invalid. ${ }^{120}$

In practical effect by far the most important relaxation of the requirement of a search warrant is that police officers making a search incident to arrest do not have to establish, in advance, probable cause to believe that the objects to be seized are at the place of arrest. If the arrest takes place, the search can then be made incident thereto. Although a District of Columbia case lield that the officers could not deliberately arrange the place of arrest so as to be able to make a search incident thereto, the Government there was unable to justify the place of arrest on any other grounds. ${ }^{121}$ In most cases, however, where police officers do not avoid obvious and safe opportunities to arrest a defendant and where they make their arrest before beginning any searcli, ${ }^{122}$ the courts have not questioned their judgment and have held the search proper as one incident to an arrest. ${ }^{123}$ This state of the law has been ironically summarized by Judge Learned Hand: "it is a small consolation to know that one's papers are safe only so long as one is not at home."124

Since the validity of a search incident to arrest will depend in great part on the validity of the underlying arrest, the arrest warrant becomes of basic importance in the problems of search and seizure.

Althougl the origins of the arrest warrant are obscure, it probably developed out of the liue and cry of early common law. ${ }^{125}$ In any event, from the founding of the Republic ${ }^{126}$ until 1945, when the Federal Rules of Criminal Procedure became effective, the grounds for and the effects of an arrest warrant were governed entirely by state law. ${ }^{127}$ The Federal Rules of Crimi-

110 Abel v. United States, 362 U.S. 217 (1960).

120 See Charles v. United States, 278 F.2d 386, 388 (9th Cir. 1960). But see Taglavore v. United States, No. 17,214, 9th Cir., June 13, 1961 (arrest warrant for minor traffic violation did not authorize seizure of narcotics where arrest warrant was not procured in good faith). 121 McNight v. United States, 183 F.2d 977 (D.C. Cir. 1950). No other court of appeals has followed the lead of the District of Columbia Circuit in this matter.

122 See Lee v. United States, 232 F.2d 354 (D.C. Cir. 1956).

123 There appears to be a trend toward examining nuore closely the search incident to arrest. See Gilbert v. United States, decided March 30, 1961 (9th Cir.).

124 United States v. Kirschenblatt, 16 F.2d 202, 203 (2d Cir. 1926).

125 See People v. Chiagles, 237 N.Y. 193, 196, 142 N.E. 583, 584 (1923).

1261 Ors. ATr's GEN. 85, 86 (1798); United States v. Ewing, 140 U.S. 142, 143 (1891).

127 See Orfield, Warrant of Arrest and Summons Upon Complaint in Federal Criminal Procedure, 27 U. Canc. L. REv. 1 (1958). 
nal Procedure, which in this respect codified the most common state practice, provided for a warrant of arrest in three situations, (1) after an indictment; ${ }^{128}$ (2) after an information filed in court under oath; ${ }^{120}$ and (3) pursuant to a complaint sworn to before a United States Commissioner. ${ }^{180}$ The last of these is, of course, the usual arrest warrant prior to formal criminal charge.

The arrest warrant based on the complaint is provided for in rules 3 and 4 of the Federal Rules of Criminal Procedure. Rule 3 provides:

The complaint is a written statement of the essential facts constituting the offense charged. It should be made upon oath before a commissioner or other officer empowered to commit persons charged with offenses against the United States.

Rule 4 allows the issuance of a warrant of arrest by the Commissioner where the complaint indicates "there is probable cause to believe that an offense has been committed" by the defendant. The words of rule 4 would appear to indicate that, as in the case of the search warrant, the Commissioner must act on the basis of facts set out in affidavit form on the face of the complaint. Since a court reporter is not usually present before the Commissioner this requirement would facilitate review. Nonetheless, until very recently it was generally assumed that the taking of oral testimony by the Commissioner would be sufficient to supplement a written complaint which merely in general terms charged the accused with the commission of a crime. ${ }^{131}$

In only one Supreme Court case has the validity of such a Commissioner's complaint been challenged. ${ }^{132}$ In that case the arrest warrant was founded upon a complaint which recited the violation merely in the words of the statute. Furthermore, nothing on the face of the complaint indicated that the Commissioner had even taken testimony bearing upon the issue of probable cause. The Court, without deciding whether the complaint itself had to contain facts showing probable cause, held that at least the complaint should show that the Commissioner had considered evidence on the issue.

Since the Supreme Court has this term sustained a deportation arrest warrant issued by an executive official ${ }^{133}$ it would seem irrational to demand more stringent protections where the determination is made by an inde-

128 FED. R. CRDM. P. 9(a).

120 Ibid.

130 FEd. R. CRIM. P. 4.

131 See Administrative Office of the United States Courts, Manuat for Untted STATES COMMIISSTONERs 27-30 (1948).

132 Giordenello v. United States, 357 U.S. 480 (1958).

133 Abel v. United States, 362 U.S. 217 (1960). 
pendent semi-judicial officer. On the other hand, the upholding of the executive arrest warrant was based in great part on the fact that deportation was "civil" rather than "criminal" in nature. Furthermore, the question of what kind of a showing was required to authorize the executive warrant was neither raised nor considered by the Court. When this issue arises it may be that a high degree of probable cause set out in affidavit form will also be required for issuance of executive warrants.

Although the adherence to rigid requirements for obtaining an arrest warrant would appear to have a salutary effect in view of the diminished necessity for a search warrant, a statutory development extending over the past fifteen years has made even an arrest warrant unnecessary in the great majority of cases. ${ }^{134}$ To understand this development, it must be remembered that the right of the federal officer to arrest without a warrant (or with a defective warrant) is, in the absence of some governing congressional enactment, controlled by state law. ${ }^{135}$ Since until relatively recently there were very few such enactments the powers of federal officials would vary greatly from state to state. In some states the common law of arrest is still in force. ${ }^{136}$ Under it a peace officer is entitled to arrest for a felony without a warrant where he has reasonable grounds to believe that the person arrested has committed or is committing a felony. ${ }^{137}$ The private citizen under the common law can arrest for a felony under exactly the same conditions as could the peace officer with one minor restriction. The felony must indeed have been committed. ${ }^{138}$ As to misdemeanors, the powers of the private citizen and the peace officer are, at common law, exactly the same. ${ }^{139}$ Both can arrest without a warrant only for misdemeanors amounting to breaches of the peace committed in their presence. A further qualification to this misdemeanor rule is that, unlike the arrest for a felony, the arrest for a misdemeanor must be made immediately or as soon as practicable after the commission of a crime. ${ }^{140}$ In all other cases an arrest warrant is necessary to arrest for a misdemeanor.

Were the common-law rules of arrest in force in all states the primary argument for a federal law of arrest would be only that the common-law rules are relatively unsatisfactory. Certainly it is difficult to assert that these rules have any particular rational basis today. Although they may

134 See Warner, Investigating the Law of Arrest, 26 A.B.A.J. 151, 152 (1940) ("the vast majority of arrests are made without a warrant . . . .").

135 United States v. Di Re, 332 U.S. 581, 589 (1948).

136 E.g., MInN. Stat. ANn. $\$ \$ 629.34,629.37$ (1947).

137 Bell v. United States, 254 F.2d 82 (D.C. Cir. 1958).

138 See MinN. STAT. ANN. $\$ 629.37$ (1947).

1399 HaLSBURY's Laws of ENGLAND para. 117 (2d ed. 1933).

140 See Smith v. State, 228 Miss 476, 87 So. 2d 917 (1956) (one-half hour delay too great). See Annot, 58 A.L.R.2d 1052 (1958). 
have been a satisfactory adjustment between the right of the citizen to sue for invasion of his privacy by trespass or false imprisonment and the interest of the government in apprehending criminals, it is not so clear that the same technical standards of legal arrest should apply where the sole question concerns the apphication of the exclusionary rule.

First of all, the rigid rules as to misdemeanors, though they have had little effect on federal officials, have made local law enforcement in many areas ineffectual. It is not coincidence that many of the greatest local law enforcement problems-gambling, prostitution, and serious traffic offenses, such as drunken and hit-and-run driving-are misdemeanors.

On the other hand, the broad powers of arrest without a warrant for felonies may have been quite reasonable when there were only six commonlaw felonies, all of which involved either violence or some great threat to the state. These powers are more difficult to justify today when the great bulk of non-regulatory federal crimes-ranging from false statements to government officials ${ }^{141}$ through almost all narcotics and bootlegging offences to the mailing of obscene photographs ${ }^{142}$-are felonies. Moreover, the great distinctions made between the powers of arrest for felonies and for misdemeanors are not matched by any clarity in the differences between the types of crime themselves. In most states the difference between misdemeanor and felony theft depends upon the exact value of the material stolen. ${ }^{143}$ In gambling offenses the difference often depends upon whether the defendant has been previously convicted. ${ }^{144}$

Dissatisfaction with the common-law rules of arrest has created another problem-lack of uniformity. Many states have attempted to improve them in varying ways. Typical of these modifications is the rule which allows the private citizen to arrest only for an offense-felony or misdemeanor-committed in his presence. ${ }^{145}$ In other jurisdictions, the riglit to arrest without a warrant for a felony has been contracted to cases where for some reason, such as the imminent escape of the defendant, it is impractical to secure an arrest warrant. ${ }^{146} \mathrm{~A}$ factor further complicating this lack of uniformity is the differing eharacterizations of the federal officer in different states. In most the federal officer is merely a private person with no greater power of arrest than the ordinary private citizen, ${ }^{147}$ while in some he is a peace officer with powers similar to those of the deputy sheriff. ${ }^{148}$

14118 U.S.C. $\$ 1001$ (1958).

14218 U.S.C. $\S 1461$ (1958).

143 E.g., Ir工. Rev. Stat. ch. $38, \S \S 389,585$ (1959) (larceny of less than $\$ 300$ is misdemeanor).

144 See Itr. Rev. Stat. ch. 38, $\S \S 346,585$ (1959) (3d gambling offense is felony).

145 E.g., Tr.. Rev. StaT. ch. 38, § 657 (1959).

146 See Texas Code Crma. Proc. art. 215 (1948).

147 See, e.g., Cat. Pen. Code $\$ 817$; N.Y. Code Crma. Proc. \& 154.

148 WIs. Stat. § 939.22 (1957). 
In view of the many hyperfine distinctions drawn in the state laws of arrest and the wide variations from jurisdiction to jurisdiction, it was not at all unreasonable for Congress to relieve federal officers from subjugation to state law and to create instead a rational modern federal law of arrest. Unfortunately, as the statutory development shows, Congress had no coherent plan to accomplish this. In 1935 United States Marshals, whose powers had previously been determined by state law, were given federal power to make an arrest without warrant for a felony where that felony had indeed been committed. ${ }^{149}$ In 1948 this power was expanded by eliminating the requirement that the felony must have actually been committed. ${ }^{150}$ Since there are only approximately 800 Marshals and Deputy Marshals, most of whose duties are confined to serving civil complaints and subpoenas, keeping records, and transporting federal prisoners, their right to arrest without a warrant has had little practical impact and has rarely been litigated. ${ }^{151}$ The right of arrest of the some 6,000 Federal Bureau of Investigation agents is somewhat more important. In 1934 FBI agents were given federal power to arrest for a felony actually committed where it reasonably appeared that the person arrested was likely to escape before a warrant could be obtained. ${ }^{152}$ In the ensuing years this power was expanded in three directions. First, in 1948 the restriction that the felony must indeed have been committed was removed. ${ }^{153}$ Second, in 1951, as a result of two cases in which the Second ${ }^{154}$ and District of Columbia ${ }^{155}$ Circuits came to opposite conclusions as to the legality of the same arrest, the requirement that the person arrested be likely to escape was removed. ${ }^{156}$ Third, the right of arrest without a warrant was extended even to misdemeanors not amounting to breaches of the peace. ${ }^{157}$ Since 1951 the authority of almost all federal law enforcement agencies-with the notable exception of the Postal Inspection Service ${ }^{158}$ - has been broadened by statute to be as great or greater than the already broad common law of arrest without a warrant. ${ }^{159}$

We may then ask just what good is an arrest warrant-or more precisely, when will a police officer have greater power with an arrest warrant than without one. The answer, strangely enough, is almost never. True, no

149 Act of June 15, 1935, ch. 259, § 2, 49 Stat. 378 (now 18 U.S.C. $\$ 3053$ (1958)).

16018 U.S.C. $\S 3053$ (1958).

151 Needless to say this situation may change drastically if Deputy U.S. Marshals are used to keep order during desegregation disputes. See N.Y.Times, May 23, 1961, p. 1, col.6.

162 Act of June 18, 1934, ch. 595, 48 Stat. 1008 (now 18 U.S.C. $\$ 3052$ (1958)).

163 Act of June 25,1948 , ch. 645,62 Stat. 817 (enacting 18 U.S.C. $\$ 3052$ ).

154 United States v. Coplon, 185 F.2d 629 (2d Cir. 1950).

158 Coplon v. United States, 191 F.2d 749 (D.C. Cir. 1951).

15618 U.S.C. $\$ 3052$ (1958).

15718 U.S.C. $\$ 3052$ (1958).

158 See Macris, The SilEnt Investigators (1959).

15918 U.S.C. $\$ 3056$ (1958), as amended, 18 U.S.C. $\$ 3056$ (Supp. I, 1959) (Secret Service). 
federal officer can arrest for a misdemeanor committed outside of his presence and for officers other than Federal Bureau of Investigation agents, an arrest warrant is necessary for almost all misdemeanors not amounting to breaches of the peace. In the usual cases of arrest for a felony, however, the only advantage of an arrest warrant is that the officer armed with it need not himself know the facts constituting probable cause to believe that the person to be arrested had committed the crime. However, since two recent Supreme Court decisions ${ }^{160}$ have held that hearsay information from a reliable informant is sufficient to constitute probable cause, the investigative officer making the arrest needs only to have had the probable cause informally communicated to him by another agent-presumably reliableor have examined his own agency's files in the matter. Since in the usual case the agent would not be making the arrest under any other circum. stances, the arrest warrant can be seen to have almost no value. ${ }^{101}$

As a practical matter an arrest warrant in some cases may even prove a disadvantage to arresting officers. Where officers have both an arrest warrant for a misdemeanor and probable cause to arrest for a felony, the arrest may be held illegal if the warrant is technically defective. Although the officers without any warrant may arrest for a felony, the presence of the misdemeanor warrant may be held to bar them from claiming a felony arrest. ${ }^{162}$ Furthermore, according to a recent court of appeals decision, federal officers may be prevented from testifying in a state prosecution concerning illegally seized evidence only if they have seized the evidence while armed with a warrant. ${ }^{163}$ In cases where an illegal search and seizure are made with no warrant at all, according to this decision, the defendant cannot enjoin the use of the evidence in the state court.

It is no means clear that this anomalous condition of the law will be allowed to continue much longer, ${ }^{164}$ although an attempt to provide District of Columbia police with an incentive to get an arrest warrant has apparently been abandoned. In Accarino v. United States ${ }^{165}$ the Court of Appeals for the District of Columbia Circuit held that police officers without a warrant may not enter a dwelling —either violently or peacefully_to make an arrest, unless there are some circumstances necessitating quick action so

160 Draper v. United States, 358 U.S. 307 (1959) ; Jones v. United States, 362 U.S. 257, 270 (1960).

161 In the conımon case where the agent after such communication still did not have probable cause no arrest could be nade without a warrant. Presumably in such a case no arrest warrant could be procured, either.

162 Cf. Clay v. United States, 239 F.2d 196 (5th Cir. 1956); but cf. Donahue v. United States, 56 F.2d 94 (9th Cir. 1932).

163 Wilson v. Schnettler, 275 F.2d 932 (7th Cir. 1960), aff'd on other grounds, 365 U.S. 381 (1961).

164 The court in Bolger v. United States, 189 F. Supp. 237 (S.D.N.X.1960) expressly refused to follow the view of the 7th Circuit in Wilson v. Schnettler, supra note 163.

165179 F.2d 456 (D.C. Cir. 1949). 
that resort to a magistrate is impracticable. In Morrison v. United States ${ }^{166}$ this rule was watered down by the implication that officers might indeed enter the dwelling without a warrant if they were positive that their quarry was within. More recently the District of Columbia Circuit has allowed officers without a warrant to enter a dwelling to make an arrest even though they could not be sure the defendant was within and even though no circumstances necessitated quick action. ${ }^{167}$ Several courts, however, have recently hinted that any arrest without a warrant, whether or not in a dwelling, will be held to require a higher degree of probable cause in those cases where a resort to a magistrate would have been practicable. ${ }^{168}$ Moreover, in an effort to encourage police to procure a warrant, two courts of appeals have recently revived a rule giving a type of presumptive validity to a Commissioner's finding of probable cause. In one the court stated that the decision of the Commissioner as to probable cause can be the decisive factor where that question is close. ${ }^{169}$ Another court of appeals has gone further and stated that the judgment of the Commissioner as to probable cause is conclusive unless arbitrarily exercised. ${ }^{170}$ In view of the fact that most courts have heretofore regarded the question of probable cause as a legal one within their purview, it is difficult to say how this effort to encourage police to obtain warrants will fare. ${ }^{171}$

Until very recently the fourth amendment was the only ground for suppressing probative and relevant evidence. The suppression sanction, however, has been apphed lately in two non-constitutional areas. The first of these involves rule 5(a) of the Federal Rules of Criminal Procedure which requires that a person arrested be brought before a United States Commissioner and arraigned without unreasonable delay. The suppression sanction here was originally invoked in $M c N a b b$ v. United States ${ }^{172}$ to exclude a confession made during a long period of detention without arraignment. This exclusionary rule resulted primarily from the feeling of the Court that any uncontrolled period of custody in police officers' care was replete with such dangers of coercion, both physical and psychological, that no statements made by the accused under illegal detention before arraignment should be admissible.

168262 F.2d 449 (D.C. Cir. 1958).

187 Washington v. United States, 263 F.2d 742 (D.C. Cir. 1959). See also Smith v. United States, 254 F.2d 751 (D.C. Cir. 1958).

168 Clay v. United States, 239 F.2d 196 (5th Cir. 1956) ; Hopper v. United States, 267 F.2d 904 (9th Cir. 1959). See also Smith v. United States, 254 F.2d 751, 754 (D.C.Cir.1958); United States v. Volkell, 251 F.2d 333 (2d Cir. 1958).

109 United States v. Ramirez, 279 F.2d 712, 716 (2d Cir. 1960).

170 Evans v. United States, 242 F.2d 534, 536 (6th Cir. 1957).

171 See Steele v. United States No. 2, 267 U.S. 505 (1925) ; United States v. Office No. 508 Ricou Brewster BIdg., 119 F. Supp. 24 (W.D. La. 1954) ; but see Gracie v. United States, 15 F.2d 644 (1st Cir. 1926).

172318 U.S. 332 (1943). 
The use of suppression here can be defended on two grounds. First, although rule 5 (a) is not of constitutional dimension it has strong constitutional overtones. The interest of society in preventing the use of any type of coerced confession is so great that even where coercion is only a possibility we must make completely certain that the confession not be used. Secondly, it is not unreasonable to deny to the prosecution the use of a statement which would not have existed had rule 5 (a) been complied with. ${ }^{173}$ This is somewhat different from denying to the prosecution evidence which merely might not have been found at that time had the illegal search and seizure not taken place.

Although the suppression sanction here has been applied almost exclusively to confessional evidence, a recent Second Circuit case has held that even physical evidence procured from the accused during a period of illegal delay should be suppressed. ${ }^{174}$ This rule has been criticized as an irrational extension of the $M c N a b b$ doctrine, contributing in no way to the purposes of that rule, since obviously the physical evidence would not be subject to the unrehability of a coerced confession. ${ }^{175}$ This criticism, however, is not completely valid since a subsidiary purpose of the $M c N a b b$ rule was to discourage illegal arrests without probable cause by officials who might thereafter attempt to get the necessary evidence either from the lips of the accused or otherwise, before it was necessary to begin the judicial proceedings by arraignment. ${ }^{176} \mathrm{It}$ is too early to tell whether other courts will follow the lead of the Second Circuit in this matter or whether they will hold that the disadvantages of applying the suppression sanction will in this case outweigh the more indirect effects of its application.

The second non-constitutional ground for invoking the suppression sanction is the relatively little known section 3109 of title 18, United States Code, whicl provides, "The officer may break open any outer or inner door or window of a house, or any part of a house, or anything therein, to execute a search warrant, if, after notice of his authority and purpose, he is refused admittance...."

Although on its face this statute merely grants certain powers to an officer executing a search warrant, the venerable common-law history of this enactment and its predecessor ${ }^{177}$ is much broader. At common law after Semayne's Case ${ }^{178}$ in 1603, no officer executing a search warrant or an arrest warrant, or arresting without a warrant, ${ }^{179}$ could force his way into

173 See United States v. Mitchell, 322 U.S. 65 (1944).

174 United States v. Klapholz, 230 F.2d 494 (2d Cir. 1956).

175 See Note, Suppressions of Non-Confessional Evidence Under Rule 5(a) of Federal Rules of Criminal Procedure, 66 YAIE. L.J. 270 (1956).

$178 \mathrm{McNabb}$ v. United States, 318 U.S. 332, 344 (1943).

${ }^{177}$ Act of June 15, 1917, ch.30, tit. XI, \$\$ 8, 9, 40 Stat. 229.

17877 Eng. Rep. 194 (1603).

178 See Wilgus, Arrest Without a Warrant, 22 Mrcr. L. Rev. 798, 806 (1924). 
a private dwelling without first knocking and giving notice of his authority. The reason for this rule was originally said to be grounded on the fear of unnecessary damage to private property caused by officers breaking into houses where they might, had they asked, have been admitted freely. ${ }^{180}$ In discussing this principle, therefore, we must note carefully that it applies only in those cases where the officers, acting under a warrant or otherwise lawfully, have a right to be on the premises and to invade the privacy of the citizen. Hence the application of this rule must be carefully distinguished from the problems arising under the fourth amendment.

It is interesting to note that the first recorded application of this statute to suppress the results of a search occurred in Woods $v$. United States, ${ }^{181}$ decided in 1956. In that case officers possessing a search warrant knocked at the door of a suspected bookie parlor. Receiving no response to their knock they pushed open the door and found four men surrounded by the usual gambling paraphernalia. In view of the background of the statute the District of Columbia Circuit held that by a negative preguant it forbade officers armed with a search warrant from breaking into a dwelling without announcing their purpose. The court then, without discussion, assumed that any violation of this statute would call for the suppression of any evidence thereby discovered. It is not at all obvious that the failure of the officers to do more than knock before opening the door is such a serious violation of individual rights as to call for the invocation of the suppression sanction. On the other hand, the Woods case can be defended on the ground that the procedure for obtention and service of search warrants is carefully spelled out, and that any non-trivial departure from these will invalidate the warrant and hence the search. Two years later, however, the statute's application was extended by the Supreme Court to cover a much larger class of cases-the searches incident to arrest. In Miller v. United States, ${ }^{182}$ the officers had probable cause to arrest the defendant but gave insufficient notice of their purpose before breaking in. The Supreme Court comprehensively reviewed the background of section 3109 and concluded that the statute required notice by police officers before any breaking into a home whether pursuant to a search warrant or not. The Court, again without discussion, assumed that a violation of this statute would require suppression of any evidence so discovered. This result can be defended only

180 77 Eng. Rep. 194, 196 (1603), "for the law without a default in the owner abhors the destruction or breaking of any house (which is for the habitation and safety of man) by which great damage and inconvenience might ensue to the party, when no default is in him; for perhaps he did not know of the process, of which, if he had notice, it is to be presumed that he would obey it ...."

181240 F.2d 37 (D.C. Cir. 1956). There are portents of the result in Accarino v. Umited States, 179 F.2d 456 (D.C. Cir. 1949), but the court in Accarino makes no mention of $\$ 3109$. 182357 U.S. 301 (1958). 
on the conceptual ground that the breaking invalidates the arrest and that the lack of a lawful arrest makes the search unconstitutional. It is hard to see, however, that section 3109 is so fundamental that it must be protected by the suppression sanction.

Perhaps the main problem under section 3109 is not whether the statute is a fundamental guarantee, but whether despite its ancient origins it has any place in modern law. ${ }^{183}$ The Court in the Miller case was dealing with a narcotics peddler in a situation where the contraband was small and could be easily destroyed before police officers could enter. Nonetheless the Government expressly disclaimed any attempt to support the entry on the ground that section 3109 contained an implied exception where evidence might be destroyed or violence might be expected. The Supreme Court therefore specifically refused to rule on this question.

Admittedly, such an exception would almost swallow up the rule. But it would seem that the perfection of small firearms and the development of indoor plumbing through which evidence can quickly be destroyed, have made section 3109 a dangerous anachronism. In many situations today where bandits are captured only after long gun battles with police, a rule requiring officers to forfeit the valuable element of surprise seems senseless and dangerous.

Certainly this is not to say that officers arresting for income tax evasion or anti-trust violations are privileged to batter down doors before asking admission. Presumably, in this type of situation sanctions other than suppression would be more appropriate anyway.

A recent court of appeals case involved a most interesting application of section 3109. In Leahy v. United States, ${ }^{184}$ government agents armed with an arrest warrant had secured entry into the defendant's home by fraud. The defendant inoved to suppress the results of the search incident to his arrest on the ground that the entry was in violation of section 3109 . The court, however, held that the statute merely prevents breaking im without notice; here, where the officers had not broken in, the statute was inapplicable. On first glance this appears to be an overly technical ruling, especially in view of the many cases equating fraud with force under the fourth amendment. ${ }^{185}$ It should be noted, however, that the court's reasoning is completely in keeping with the common-law history and purposes of the statute to protect property from the unnecessary injury of a forcible

183 There have been suggestions in two cases, Hopper v. United States, 267 F.2d 904 (9tb Cir. 1959), and United States v. Macri, 185 F. Supp. 144 (D. Conn. 1960), that the interpretation of $\$ 3109$ is determined by reference to state law. It is difficult to defend this proposition as applied to a federal statute.

184272 F.2d 487 (9th Cir. 1959), cert. granted, 363 U.S. 810 (1960), petition for cert. dismissed on motion of petitioner, 364 U.S. 945 (1961).

185 See, e.g., Gouled v. United States, 255 U.S. 298 (1921); Fraternal Order of the Eagles v. United States, 57 F.2d 93 (1932). 
entry rather than to guard the rights of privacy involved in the fourth amendment.

It is possible that many of the niceties in the law of search and seizure result because the suppression sanction, while the most effective method of preventing illegal invasions of privacy, is also more drastic than many courts are willing to accept. To avoid freeing the criminal in the concrete case before them, courts will often strain to make exceptions to the fourth amendment so that relatively minor errors by police officers do not lead to the escape of much more serious offenders. One unfortunate result of this process is the relaxation of protections of individual rights in certain areas, such as eavesdropping, where they are most needed. Another result is the anomaly of the courts' erecting strict requirements for search and arrest warrants and then allowing police officers almost equal freedom without these documents.

On the other hand, in various situations the unquestioned application of the suppression sanction has placed too great a restriction on legitimate law enforcement activities. The preservation of the means and instrumentalities test, the implementation of title 18 , section 3109 , and the general application of the fourth amendment to cases where the basis of the alleged deprivation of constitutional right lies not in the search itself, but in the failure to observe some technical preliminary and often statutory distinction are the clearest examples.

In such a complex field as search and seizure, it is impossible to suggest one great principle which, if applied, would automatically lead to a perfect and rational balance between the rights of the individual to privacy and the interest of law enforcement agencies, and society itself, in discovering evidence against and apprehending criminals. One thing, however, is clear: the working out of the guarantees and content of the fourth amendment is by no means complete. Before a satisfactory solution is achieved, a great deal more experimentation will be required. In this respect, it is regrettable that the Supreme Court, in overruling Wolf v. Colorado ${ }^{186}$ spoke in such broad terms ${ }^{187}$ and apparently applied the full body of federal search and seizure law to the states. ${ }^{188}$ It is difficult to believe that the many minor as well as major irrationalities in the law of search and seizure have suddenly achieved constitutional dimension. It is possible that in future cases the Supreme Court will more explicitly recognize the great virtue of federalism in approaching these problems and apply the exclusionary rules to the states only when a serious or intentional breach of the right of privacy occurs. ${ }^{189}$ It remains, however, for future litigation to resolve this point.

186338 U.S. 25 (1949).

187 See Mapp v. Ohio, 81 Sup. Ct. 1684, 1693-94 (1961).

188 See Elkins v. United States, 364 U.S. 206, 223-24 (1960).

189 Such a breach was involved in Mapp v. Ohio, 81 Sup. Ct. 1684, 1698 (1961). 